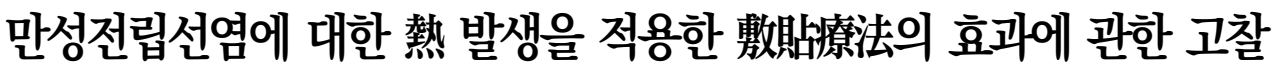

\author{
서희정 ${ }^{1,2}$, 배고은 ${ }^{1,2}$, 최진용 ${ }^{1,2}$, 심소현 ${ }^{1,2}$, 서형범1,2, 김소연 1,2 , 권정남 ${ }^{1,2}$ \\ 윤영주 ${ }^{1,2}$, 이인 ${ }^{1,2}$, 최준용 ${ }^{1,2}$, 한창우 ${ }^{1,2}$, 홍진우 ${ }^{1,2}$, 박성하 ${ }^{1,2^{*}}$ \\ ${ }^{1}$ 부산대학교한의학전문대학원, ${ }^{2}$ 부산대학교 한방병원 한방내과
}

\section{Review of Effect on Heat-generating Plaster Therapy for Chronic Prostatitis}

Hee Jeong Seo ${ }^{1,2}$, Goeun Bae ${ }^{1,2}$, JinYong Choi ${ }^{1,2}$, SoHyun Shim ${ }^{1,2}$, HyungBum Seo ${ }^{1,2}$, So Yeon Kim ${ }^{1,2}$, JungNam Kwon ${ }^{1,2}$ YoungJu Yun ${ }^{1,2}$, In Lee ${ }^{1,2}$, JunYong Choi ${ }^{1,2}$, ChangWoo Han ${ }^{1,2}$, JinWoo Hong ${ }^{1,2}$, SeongHa Park ${ }^{1,2^{*}}$

\author{
${ }^{1}$ School of Korean Medicine, Pusan National University \\ ${ }^{2}$ Department of Internal Medicine of Korean Medicine, Pusan National University Korean Medicine Hospital
}

Objectives: The aim of this study is to investigate the effect of Heat-generating plaster therapy on Chronic prostatitis Methods: We searched articles from Academic Journals(CAJ) online databases. Searching keywords were '貼數, "慢性前列腺炎', '數貼”, “慢性前列腺炎”.

Results: Among the articles published until October 2017, The 18 articles were found. After reviewing the title, abstract and original article, the 3 articles were selected finally to rule out completely different prescriptions.

Conclusions: The effect of Heat-generating plaster therapy on symptoms such as urinary frequency, dysuria, nocturia and sexual dysfunction due to chronic prostatitis was satisfactory. Especially the method is simple and safe, easy to use, patient-friendly, and convenient.

Key Words : Heat-generating, Plaster therapy, Chronic prostatitis, Patient-friendly

\section{서 론}

만성전립선염은 울혈성심부전과 협심증, 크론병 및 당뇨병과 함께 환자의 삶의 질에 심각한 영향을 미치 는 네 가지 질병으로 분류했는데 만성전립선염의 병인 은 매우 복잡하며 많은 치료방법이 있지만 특별한 치 료법이 없으며 치료 결과가 만족스럽지 못하고 통일되 고 표준화 된 치료 프로그램도 부족하다1).
특히 발병 원인에 있어 여러 요인이 있으나 각각 단 일요인으로 나타나지 않으며 복합적으로 나타나므로, 그 동안 단일요법으로 치료했던 치료법이 최근에는 환 자에게 나타난 여러 원인을 찾고, 그 복합된 원인에 동 시에 대응하는 치료법이 사용되고 있다2).

한의학에서도 전통의 한약, 침구치료와 함께 外治法 으로 中藥坐浴, 穴位敷貼, 中藥保留灌腸, 尿道灌注 등 다양한 치료가 함께 이루어지고 있달.

\footnotetext{
- Received : 24 May 2018 - Revised : 11 June 2018 -Accepted : 11 June 2018

- Correspondence to : 박성하(Seong Ha Park)

Department of Internal Medicine, Pusan National University Korean Medicine Hospital, Beomeo-ri, Mulgeum-eup, Yangsan-si, Gyeongsangnam-do, 50612, Korea.

Tel : +82-55-360-5600 Fax : +82-55-360-5559, E-mail : psh0680@hanmail.net
} 
이 중 敷㙋요법은 經穴부위에 작용하기 때문에 진단 에 따른 시술을 할 수 있으며, 특히 장시간의 시술 시 간 동안 사용할 수 있어 지속적인 치료 효과를 볼 수 있다.

姜年은 전립선염에 고주파 전자기장의 작용을 이용한 熱療機치료와 穴位를 이용한 藥物敷貼治療를 병행한 결 과 藥物數貼治療만 한 것보다 효과적이었음을 발표하였 다. 熱을 발생시키는 敷㙋요법의 경우 熱療機가 없어도 미세 순환을 개선하고 혈액 순환을 촉진하며 除濕止痛, 溫經通絡, 暖胃散寒의 효과가 있고, 특히 치료시간에 있어 10시간 이상의 치료시간이 지속되므로 風濕性關 節痛、腰腿痛、腰肌勞損、軟組織損傷, 胃寒, 腹痛, 疼痛 등 에 진통효과가 있는 등 치료 시 유의한 효과와 함께 고 통스런 통증 및 심각한 부작용이 없어 中醫에서는 많은 敷貼劑가 개발되어 사용되고 있다5).

따라서 저자는 온라인 데이터베이스 검색을 통해 만 성전립선염에 熱 발생을 적용한 敷㙋요법에 관한 임상 연구들을 조사하여 그 효과를 분석함으로써, 향후 만성 전립선염의 치료에 도움이 될 것으로 보고 본 연구에 임하였다.

\section{연구방법}

\section{1. 데이터베이스 선택 및 검색}

2017년 까지 Chinese Academic Journals(CAJ) 의 온라인 데이터베이스를 활용하여 만성전립선염에 대 하여 熱 발생을 적용한 敷貼治療의 효과를 검색하였다.

검색어는 ‘貼敷', ‘慢性前列腺炎”, 敷㙋’, ‘慢性前列腺 炎'을 사용하였다(Fig.1). 검색 기준일은 2017년 10 월 23일이다.

\section{2. 포함 연구 자료 분석}

본 연구는 만성전립선염에 대한 열을 적용한 敷㙋요 법의 치료 효과에 대한 고찰로서, 최종 선정된 각 논문 들의 원문을 검토한 뒤 핵심 정보를 추출하였다. 선정 된 논문들의 연구 디자인, 대상 질환, 적용된 중재, 대 조군, 평가지표, 주요 결과, 저자의 결론 등을 각 논문 별로 정리하여 서술적인 분석을 하고, 이를 표로 정리 하였다(Table 1).

Table 1. Data of Clinical Studies of Heat Application Therapy for Chronic Prostatitis

\begin{tabular}{|c|c|c|c|c|c|c|}
\hline $\begin{array}{c}\text { First } \\
\text { Author } \\
\text { (Year) }\end{array}$ & $\begin{array}{l}\text { Sample } \\
\text { size }\end{array}$ & Intervention & Control & $\begin{array}{l}\text { Primary } \\
\text { Outcome }\end{array}$ & Main Result & Author's Conclusion \\
\hline $\begin{array}{l}\text { JIANG J } \\
(2011)^{4)}\end{array}$ & $\begin{array}{l}\text { Total } \mathrm{n}=124 \\
\cdot \text { Control } \\
\text { Group } \\
\mathrm{n}=62) \\
\text { - Treatment } \\
\text { Group } \\
\mathrm{n}=62)\end{array}$ & $\begin{array}{l}\text { · Routine } \\
\text { symptomatic } \\
\text { reatment } \\
\text { · Patch posted on } \\
\text { acupoints } \\
\text { : 關元, 腎俞, 膀胱 } \\
\text { 俞, 中㥛, 陰交等 } \\
\text { - Quadrupole } \\
\text { projection therapy } \\
\text { (the other prostate } \\
\text { heat therapy } \\
\text { machine) }\end{array}$ & $\begin{array}{l}\text { · Routine } \\
\text { symptomatic } \\
\text { treatment } \\
\text { · Patch posted on } \\
\text { acupoints } \\
\text { : 關元, 腎俞, 膀胱 } \\
\text { 俞, 中㥛, 陰交等 } \\
\end{array}$ & $\begin{array}{l}\text { - Symptoms } \\
\text { - Prostatic } \\
\text { fingerprinting } \\
\text { - Prostatic fluid } \\
\text { microscopy } \\
\text { - Segmented urine } \\
\text { and prostatic fluid } \\
\text { bacterial localization } \\
\text { test }\end{array}$ & $\begin{array}{l}\text { - Symptoms disappeared, improve the } \\
\text { quality of prostatic fingerprinting ( } \mathrm{P}<0.05 \text { ) } \\
\text { - Prostatic fluid microscopy, continuous } 2 \\
\text { to3 times normal, prostatic fluid } \\
\text { leukocyte count was normal } \\
\text { - Segmented urine and prostatic fluid } \\
\text { Bacterial localization test EPS, VB3 } \\
\text { bacterial culture was negative } \\
\text { - ButEPS, VB3 bacterial culture was not } \\
\text { negative; invalid: no improvement of } \\
\text { symptoms, signs and various tests. }\end{array}$ & $\begin{array}{l}\text { - The use of hyperthermia } \\
\text { machine with acupuncture } \\
\text { points for the treatment of } \\
\text { CABP can rapidly improve } \\
\text { clinical symptoms and } \\
\text { improve patient quality of life, } \\
\text { and no pain and adverse } \\
\text { reactions. }\end{array}$ \\
\hline $\begin{array}{l}\text { WEN N } \\
(2009) 6)\end{array}$ & $\begin{array}{l}\text { Total } \mathrm{n}=60 \\
\cdot \text { Control } \\
\text { group } \\
(\mathrm{n}=30) \\
\cdot \text { Treatment } \\
\text { group } \\
(\mathrm{n}=30)\end{array}$ & $\begin{array}{l}\text { · Heat plaster } \\
\text { therapy } \\
\text { : 神咸, 中極, 命門 } \\
\text { (Jiangxi Ai } \\
\text { Biological } \\
\text { Technology Co., } \\
\text { Ltd.) }\end{array}$ & $\begin{array}{l}\text { · Acupuncture } \\
\text { : 中極, 次髎, 行間, } \\
\text { 歸來, 三陰交 }\end{array}$ & $\begin{array}{l}\text { - Symptoms } \\
\text { - High magnification } \\
\text { of prostatic fluid } \\
\text { leukocytes }\end{array}$ & $\begin{array}{l}\text { There was a significant difference in the } \\
\text { post-treatment effect between the two } \\
\text { groups }(\mathrm{P}<0.01) \\
\text { - The total efficacy rate was } 83.3 \% \text { in the } \\
\text { Treatment group and } 70.0 \% \text { in the } \\
\text { control group, but there was no } \\
\text { significant difference between the two } \\
\text { groups }(\mathrm{P}>0.05)\end{array}$ & $\begin{array}{l}\text { - The effect of heat therapy on } \\
\text { symptoms such as urinary } \\
\text { frequency, dysuria and } \\
\text { nocturia due to chronic } \\
\text { prostatitis was satisfactory. } \\
\text { - Method is simple and safe, } \\
\text { easy to use, no acupuncture } \\
\text { pain, patient-friendly and } \\
\text { con-venient. }\end{array}$ \\
\hline
\end{tabular}




\begin{tabular}{|c|c|c|c|c|c|c|}
\hline $\begin{array}{l}\text { First } \\
\text { Author } \\
\text { (Year) }\end{array}$ & $\begin{array}{l}\text { Sample } \\
\text { size }\end{array}$ & Intervention & Control & $\begin{array}{l}\text { Primary } \\
\text { Outcome }\end{array}$ & Main Result & Author's Conclusion \\
\hline $\begin{array}{c} \\
\text { GAO } \\
\text { XD } \\
(2009) 7)\end{array}$ & $\begin{array}{l}\text { Total } \mathrm{n}=130 \\
\cdot \text { Chronic } \\
\text { non- } \\
\text { Bacterial } \\
\text { prostatitis } \\
(\mathrm{n}=102) \\
\cdot \text { Chronic } \\
\text { bacterial } \\
\text { prostatitis } \\
(\mathrm{n}=28)\end{array}$ & $\begin{array}{l}\text { · Heat plaster } \\
\text { therpy } \\
\text { : 神關, 中極, 命門 } \\
\text { (Jiangxi Ai } \\
\text { Biological } \\
\text { Technology Co., } \\
\text { Ltd.) }\end{array}$ & - None & $\begin{array}{l}\cdot \text { Symptoms } \\
\cdot \text { The digital rectal } \\
\text { Examination } \\
\cdot \text { Prostate fluid } \\
\text { routine smear }\end{array}$ & $\begin{array}{l}\text { - Symptoms disappeared } \\
\text { - The prostatic glands returned to normal } \\
\text { or near normal in the digital rectal } \\
\text { examination. } \\
\text { - In the prostate fluid routine smear the } \\
\text { normal } 112 \text { cases }(86.2 \%) \text {, the maximum } \\
\text { flow rate significantly increased or } \\
\text { reached the normal range } \\
\text { - } 34 \text { cases were cured }(26.2 \%), 78 \text { cases } \\
(60.0 \%) \text { were improved, } 18 \text { cases } \\
(13.8 \%) \text { were ineffective, and the total } \\
\text { effective rate was } 86.2 \% \text {. }\end{array}$ & $\begin{array}{l}\text { - Hot dissolves cold and stasis } \\
\text { blood. As a result, it helps } \\
\text { blood circulation and } \\
\text { communication of meridians. } \\
\text { - Also urinary frequency, } \\
\text { dysuria, urinary closure, and } \\
\text { nocturia caused from chronic } \\
\text { prostatitis have more } \\
\text { effectiveness. } \\
\text { - The therapy is non-surgical } \\
\text { treatment, with no pain, no } \\
\text { trauma }\end{array}$ \\
\hline
\end{tabular}

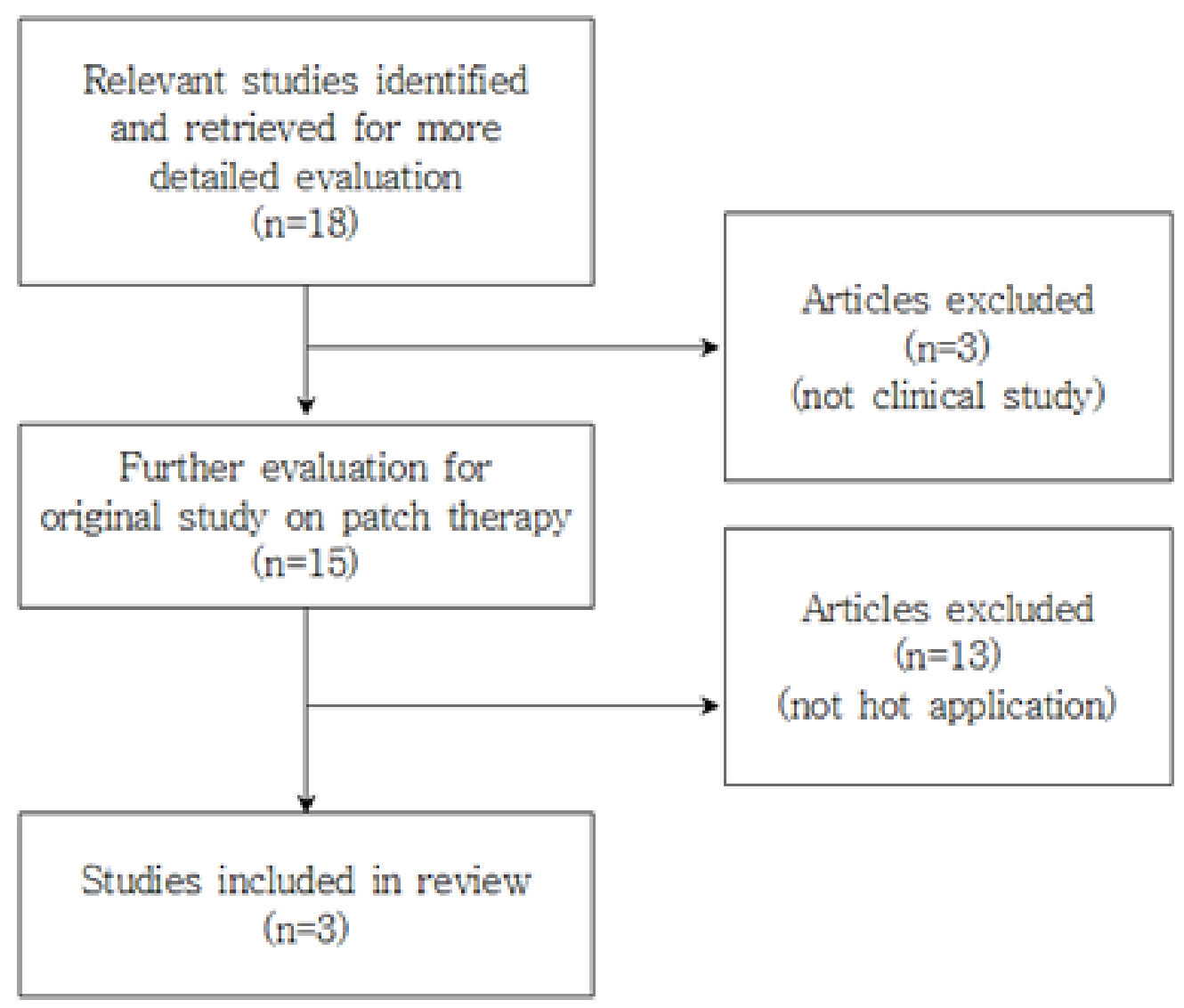

Fig. 1. Flow Chart of Clinical Study Selection 


\section{결 과}

\section{1. 자료 선별}

2017년 10월까지 발표된 논문들 중에서 CAJ의 데 이터베이스를 이용한 검색을 통해 총 18 편의 논문을 발견하였다. 이 논문들의 제목과 초록, 원문을 검토하 여 熱을 적용하지 않은 韓藥敷㙋치료, 耳穴壓丸치료, 磁 石치료를 배제하여 최종적으로 3편의 논문이 선정되었 다 (Fig. 1).

\section{2. 선정 논문의 분석}

1) 대상 질환 및 평가 지표최종 선정된 3 편의 연구들은

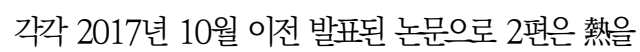

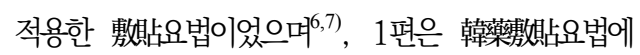
熱虏幾치료를 한 임상연구 였단)(Table 1).

\section{2) 중재 방법}

姜)의 연구에서 대조군, 치료군 모두 한약을 이용한 혈위부첩요법(關元穴, 腎俞穴, 膀胱俞, 中極, 三陰交)을 시행하였고 치료군은 병행하여 고주파를 적용한 熱尞機 를 시행하였다. 文)은 대조군과 치료군으로 무작위로 나 누어 대조군은 中極, 次膠, 行間, 歸來 三陰交에 침술치료와 전침, 烤神燈(grilled lamp)을 사용하였고 치료군은 神 關, 中極, 命門穴에 熱敷㙋 (艾慈炎-前烈線貼, 江西艾慈生 物科技有限公司生產)을 시행하였다. 高'는 대조군 없이 102예의 만성 비세균성 전립선염 환자와 28 예의 만성 세균성 전립선염환자의 神關, 中極, 命門穴 부위에 熱敷 貼 (艾慈炎 - 前烈線㙋, 江西艾慈生物科技有限公司生產) 를 시행하였다.

\section{3) 치료 효과}

각 연구에서 경혈점에 시행한 熱치료의 효과는 유의한 것 으로 니타냈다. ⿱⿱䒑土女女)은 치료결과에서 총유효율 $93.5 \%$ 로 대 조군 61.3\%에 비해 유의한 결과를 보였다. $(\mathrm{P}\langle 0.05)$

文)은 결과에서 치료군과 대조군이 치료 후 증상 점 수는 치료 전보다 유의하게 호전되었으나(P $\langle 0.01)$, 두 군 간에 유의 한 차이는 없었다(P〉 0.05). 총 유효율은
두 군 간에 유의 한 차이는 없었으며(P> 0.05) 치료군 에서 $83.3 \%$ 로 대조군에서 $70.0 \%$ 보다 높았다. 高”는 神關, 中極, 命門穴에 熱敷㙋요법을 시행한 결과 총 유효 율 $86.2 \%$ 로 유의한 효과가 있었다.

\section{고찰 및 결론}

만성전립선염의 통증으로 회음부 통증, 음경통, 고 환통, 하복통, 배뇨통과 사정통의 6가지가 있는데 이 중에서 골반 및 회음부의 통증이 특징적으로, 환자의 삶의 질에 미치는 영향이 매우 크다 ${ }^{8}$.

만성골반통증후군의 원인으로는 방광경부와 전립선 평활근 긴장도의 증가 및 요도내압의 증가에 의한 전 립선 내로의 요역류가 중요한 원인으로 고려되고 있으 며, 그 외에 자가면역질환, 성병, 전립선과 방광의 박 테리아 감염, 기능장애성 배뇨, 음낭과 회음부 및 음경 의 손상, 중추신경계와 말초신경계의 부조화 등이 알려 져 있다.)

치료에 있어 알파차단제, 항생제, 호르몬치료, 항염 증치료, 식물치료, 항경련제 그리고 비약물치료 등 많 은 치료법이 소개되었지만 다양한 치료에도 불구하고 치료효과가 만족스럽지 못하여 치료하는 의사나 환자 모두가 곤혹감을 느끼는 경우가 많다. 2,10 특히 이 치료법 들은 치료에 긍정적인 효과를 가져온 것도 있지만 효 과가 없다는 논문들도 있으며 치료법에 대한 연구의 수가 부족하거나 연구가 없는 치료 방법도 있었는데 이 이유는 요로감염, 전립선요도역류, Cytokines, pelvic floor spasm, 전신성 신경성 혹은 내분비요 인 그리고 신경정신학적인 요인 등이 복합적으로 병인 에 영향을 미치는데 이런 요인들이 하나로 나타나지 않으며 복합적으로 나타나기 때문이다.

따라서 단일요법으로 치료되었던 치료법이 최근에는 환 자에게 나타난 여러 원인을 찾고, 표현하고 있는 증상을 동시에 치료하는 복합치료법이 소개되고 있다2).

中醫學에서는 만성전립선염의 원인을 忍精不射, 手 淫無度 혹은 房室不節, 溢液敗精內阴蓝滞, 久而化濕生熱 등으로 보았으며 이濕熱이 下焦에 오래 머물러서 병이 오래되면 血脈이 㾌滞하고 결국 體虚에 이러게 되므로 
病機는 腎虛爲本, 濕熱爲標, 瘀滯爲變으로 보았다. 이에 따라 內治法은 주로 辨證論治와 辨病論治, 專病專方 등 을 위주로 하여 補腎健脾, 清利濕熱, 理氣活血法을 사용 하며 外治法은 中藥坐浴, 穴位敷貼, 中藥保留灌腸, 尿道 灌注 등으로 다양하다 ${ }^{11}$. 외치법의 경우 전립선의 특별 한 해부학적 위치에도 불구하고, 시술하기가 쉽고 국소 적 혈액 순환을 촉진하여 약물 흡수를 촉진 시키며 약 물 내성이 적고 독성 및 부작용도 적으며 장기간 치료 효과 등의 장점을 가지고 있다 ${ }^{3)}$. 특히 貼敷療法은 근년 에 임상적, 실험적 연구가 매우 활발하게 진행되고 있 는 전통적인 외치요법 중 하나로서, 약물과 經絡穴位의 二重조절작용을 발휘 할 수 있으며 두 기능은 상호협 조, 상호자극, 상호 중첩의 효과가 있으므로 단순 내복 약 비해 일정한 이점이 있달.

敷斯療法은 清代 吳師機는 “外治之理, 即內治之理; 外治之藥, 即內治之藥”이라 하여 內外治가 醫理와 藥性 에서 다르지 않다고 하였는바, 生理와 病理의 특징과 결합된 經絡이론 아래 運用되며 中醫 이론에 입각한 整 體觀念과 辨證論治가 원칙이다 ${ }^{13)}$.

이 중 熱을 이용한 敷㙋은 溫經散寒, 活血化瘀, 引經 通絡의 작용으로 만성전립선염에 기인한 빈뇨, 뇨통, 뇨폐, 야뇨에 효과적이며 비수술치료, 무통, 無創傷의 우수한 치료법이라 한닥.

聶 $^{14)}$ 은 高熱의 惡性腫留 퇴행 원인을 조사하고 腫虜 퇴 행을 위한 열역학적 기초를 제공하기 위한 연구에서 고열 에서의 腫瘤의 온도는 정상 체온보다 높았으며 腄瘤의 크 기에 따라 온도 증가의 정도는 다양하므로 고열에서 腫瘤 의 체온이 $43^{\circ} \mathrm{C}$ 에 도달하거나 종양 사망 온도에 도달하여 腫瘤 퇴행을 초래할 수 있다고 하였다.

鄧) 등은 中醫熱敷㙋으로 熱효과를 사용하면 미세 순환을 개선하여 혈액순환을 촉진하고 除濕 및 진통, 자궁 경부 및 자궁 온도 상승, 위장을 따뜻하게 하고 寒을 없애주는데, 敷貼劑로 임상 유효성 평가를 실시 한 결과 부작용은 없었고 총 유효율은 $80 \%$ 를 넘었으 며, 특히 濕性關節痛、腰腿痛、腰肌勞損、軟組織損傷、胃寒、 腹痛, 疼痛에 좋은 치료 효과가 있다고 하였다.

이에 필자는 만성전립선염에 熱을 적용한 躈㙋 의 효과를 찾기 위하여 학술연구정보서비스 (www.riss.kr/Riss)
를 통하여 만성전립선염에 대하여 국내 논문을 검색한 결과 166 편의 한•양방 논문이 있었으나 만성전립선염

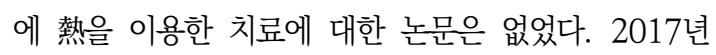
10월까지 CAJ 온라인 데이터베이스를 활용하여 '慢性 前列線炎, 敷㙋”, “慢性前列線炎, 貼敷“를 검색어로 하여 18 편의 논문을 찾았고 약물첩부치료, 이압치료, 자석 치료를 제외한 3 편의 熱을 적용한 敷貼 논문을 최종 선정하였다.

본 연구에 사용된 3편의 논문은 만성전립선 환자 중 熱을 經絡이론에 입각하여 經穴점에 시술한 경우인 데 熱療機 내지 熱敷貼를 사용하였다.

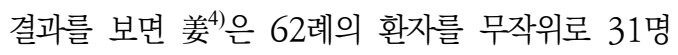
씩 대조군과 치료군으로 나누어 양군 모두 關元穴, 腎 俞穴, 膀胱俞, 中極, 三陰交 등의 穴位에 자체에서 제작 한 한약을 사용한 穴位敷貼治療貼을 붙이고 敷㙋치료 동안은 복약중인 전립선약을 중단하였다. 치료군은 ⿱宀八 位敷貼後 熱療機를 이용하여 고주파 치료를 하였다. 투 여량은 $200 \mathrm{~mA}$ 이었고 치료 시간은 30 분으로 시술하 였는데 溫熱感이나 灼熱感이 있지만 화상은 없을 정도 이며 피부에 발한이 있을 정도였다. 그는 열 효과는 전 립선 염 손상 부위의 온도를 증가시키는데, 고열에서 종양의 체온은 $43^{\circ} \mathrm{C}$ 의 종양 세포의 사망 온도에 접근 하거나 도달 할 수 있어 종양 퇴행을 초래할 수 있다 는 腫瘤熱學의 원리에 부합한다고 보았고, 아울러 고주 파 전자기장의 작용으로 세포가 분극화 방향으로 급격 히 변화하여 마찰로 인한 충격에 세포가 얇아지고 투 과성이 향상되어 약물, 산소 및 영양소의 흡입 및 대사 산물의 배출에 작용하여 면역력을 향상시키고 세포가 스스로 회복할 수 있는 능력을 증가시킨다고 보았다. 치료결과에서 자각증상 소실, 전립선은 정상 또는 개선 된 조직으로 회복되었고 전립선액 검사는 2 3번 연속 정상이었으며 소변과 전립선 액의 세균 검사에서 EPS 와 $\mathrm{VB} 3$ 세균 배양액은 음성으로 임상적 치유는 $80.6 \%$, 증상이 소실된 유효는 $12.9 \%$ 로 총유효율 93.5\%로 대조군 $61.3 \%$ 에 비해 유의한 결과를 보였다 $(\mathrm{P}<0.05)$.

文)은 만성 전립선염으로 입원한 환자 60 명을 대조군 과 치료군으로 무작위로 나누어 대조군 30예는 中極 次 
髎、行間、歸來、三陰交에 침술치료와 전침, 烤神燈(grilled lamp)을 사용하였고 留針 20 30분이었다. 치료군은 神 閶, 中極, 命門穴에 熱敷貼(艾慈炎-前烈線㙋, 江西艾慈生物 科技有限公司生產)으로 하루 10시간 이상의 열요법을 시 행하였다. 진단 기준은 빈뇨, 배뇨 장애, 요실금, 야간 빈뇨, 전립선 촉진 시 압통과 전립선이 단단하거나 부드 러운 부분이 일정치 않고, 백혈구> $10 / \mathrm{HP}$, 레시틴의 감 소 또는 소멸을 진단 기준으로 하였는데 결과 치료 후 두 군의 증상 점수는 치료 전보다 유의하게 호전되었으 나 (P〈0.01) 두 군 간에 유의 한 차이는 없었다(P〉 0.05). 총 유효율에서도 두 군 간에 유의 한 차이는 없 었으나(P>0.05) 치료군에서 83.3\%로 대조군의 70.0\% 보다 높았다.

高'는 102 예의 만성 비세균성 전립선염 환자와 28 예의 만성 세균성전립선염환자에 熱敷貼요법을 시행하였 다. 진단 기준은 배뇨 장애, 요천추부, 하복부, 회음부, 고환 등에 은은한 통증, 성기능 장애가 있고 신경쇠약증 상이 있으며, 직장수지검사 상 전립선은 약간 크고 딱딱 하며 결절과 함께 중간구가 얕아지거나 사라지고 압통이 나타나며 최대 소변양은 저하되고 백혈구의 수가 시야 당 10 개 이상이었으며 레시틴은 감소한 상태였다. 熱敷 貼 (艾慈炎-前烈線貼, 江西艾慈生物科技有限公司生產)를 매일 1貼씩 神闕 (肚胎), 中極穴 (肚臍下 4寸), 命門穴 (背後正對肚臍) 부위에 10시간 이상 번갈아 사용하여 2 3개월 동안 치료 한 환자를 추적 관찰하였다. 그 결 과 각 증상이 사라지고 직장 수지검사 상 전립선이 정상 또는 거의 정상으로 돌아왔으며 전립선액도 정상으로 회 복되었다. 112명 (86.2\%)에서 최대 소변양이 유의하 게 증가하거나 정상 범위에 도달했다. 완치된 환자는 34명 (26.2\%)이었고, 78명 (60.0\%)은 호전되었고, 18 명 (13.8\%)은 효과가 없었으며, 총 유효 비율은 $86.2 \%$ 였으며 특히 經穴 적용을 통한 열 치료는 알파 수용체를 차단하고, 소변의 저항성을 줄이며, 소변 역류 를 감소시킨다고 하였고, 환자의 임상 증상을 빠르게 개 선하고 환자의 삶의 질을 향상 시켰다고 하였다.

姜4)의 敷㙋요법에 병행한 熱療機 치료의 효과에서 고주파요법이 전자기장의 작용으로 전립선조직의 온도 가 상승하고 腺泡와 腺管의 침투가 현저하게 증가하여
약물이 腺내로 들어가는데 유리하며 동시에 혈류확장, 혈류 가속, 혈류개선, 신진대사 활성화, 백혈구의 식균 작용이 촉진되어 전립선 염증의 퇴행을 촉진하고 자극 증상이 현저하게 감소되는데 1990년대 이래 전립선 치료에 사용되었다 ${ }^{15)}$.

文 $^{(6}$ 과 高 ${ }^{7}$ 가 사용한 熱敷貼은 江西艾慈生物科技有限 公司가 제조한 “艾慈炎-前列腺貼” 으로 전통적인 뜸의 본질을 고수하고 현대적인 치료를 결합하여 뜸 치료, 자기 치료 및 원적외선치료를 결합한 쑥이 없는 뜸으 로 현대 치료법과 전통적인 뜸법의 완벽한 조화가 계

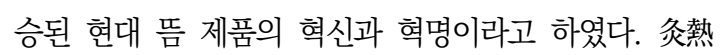
體(환원철분, 물, 식염, 탄분)와 원적외선을 발생시키는 천, 자석 및 온도조절장치로 구성되어 있고 10시간 정 도 지속적으로 사용되어 만성전립선염에서 기인한 頻 尿, 尿痛, 下腹部脹痛, 會陰部不適, 腰酸背痛에 보조요법 으로 적용 가능하다고 한다. 神關, 中極, 命門穴에 번갈 아가며 10시간 이상 사용할 수 있는데, 1) 피부 궤양, 상처, 조혈 장애 및 출혈 경향, 심장 박동기 착용자, 임플란트 등의 시술 부위 2) 건선, 홍반성 낭창, 화농 성 피부 질환, 피부 병변, 피부 감각 장애 또는 피부 알레르기, 암 환자, 급성 부상 및 염증 3) 당뇨병, 정 신병 환자, 생활 불적응자는 ⽊⽊ㅈ⺆ㄱ하라고 하였다.

자기 요법, 고열 및 원적외선요법과 경혈이론을 결 합한 熱敷㙋요법은 高熱과 活血化瘀의 효과로서 熱이 전립선에 도달하면 물분자의 회전 진동을 일으켜 $44.5 \sim 45.6{ }^{\circ} \mathrm{C}$ 로 가온시켜 혈관 확장, 혈액 순환을 증 가시켜 면역 항체를 개선시키고, 식세포가 활성화 되어 염증은 제거되고 부종은 가라앉는다. 아울러 세균의 억 제와 살균, 결합조직의 증식을 억제하고 腺管을 소통시 켜 분비물의 배설이 용이하도록 하며 염증세포의 침윤 을 막는다 ${ }^{7)}$.

이상의 결과를 볼 때 熱敷貼 요법의 효과는 1) 임상 적용에서 특별한 의료 장비가 없이 간편하고 안전하다. 2) 병원에서의 특정된 시간에 구애 받지 않아 치료시 간의 지속성이 있다. 3) 전통적인 침술에 加熱을 더한 효과와 비슷하지만 침술 통증을 원하지 않는 환자들에 게 좋다. 4) 磁療, 원적외선 요법, 뜸과 같은 다양한 전통적 치료 기능이 복합적으로 결합되어 있으며, 辨證 
에 따라 任脈(神關, 中極, 命門, 關元), 督脈(腎俞, 膀胱 俞), 足太陰脾經(三陰交)등의 다양한 穴位를 선택 치료 할 수 있다.

따라서 만성전립선염에서 기인한 빈뇨, 배뇨통, 요 로 폐쇄, 야간 빈뇨, 성기능장애 등의 증상에 熱敷貼의 사용은 經絡이론과 辨證에 바탕을 둔 한의학적 치료의 범위를 넓히고 환자 친화적인 치료법으로 임상에서 유 용하게 활용될 수 있을 것으로 사료된다.

\section{감사의 글}

이 논문은 부산대학교 기본연구지원사업(2년)에 의 하여 연구되었습니다.

\section{참고문헌}

1. Yang Z, Zhou Q. Manxing qianliexianyandezhongyi zhiliaoyanjiu jinzhan. Journal of Youjiang Medical University For Nationalities. 2013;35(3):359-361.

2. Kim KS, Lee SW. Management of Chronic Prostatitis/Chronic Pelvic Pain Syndrome (CP/CPPS). Korean J Urol Oncol. 2014;12(1):23-28.

3. Wang XB, Lu ZJ, Su Y. Research Progress on Chronic Prostatitis with External Therapy of Chinese Medicine, Journal of Nanjing University of Traditional Chinese Medicine. 2014;30(3):297-298.

4. Jiang J. Reliaoji pei he xue wei fu tie zhi liao man xing qian lie xian yan li liao xiao guan cha. Journal of Changchun University of Traditional Chinese Medicine. 2011;27(6):1016.

5. Deng K, Fan ZY. Re fu tie de zhi bei he lin chuang ying yong. Yi yao dao du. 2006;23(11):1147-1148.

6. WEN N. Re fu tie zhi liao man xing qian lie xian yan 30 li guan cha. China Medical Herald. 2009;6(36):94.

7. Gao XD. Re fu zhi liao man xing qian lie xian yan 130 li. China Modern Medicine.
2009;16(22):198.

8. Choi JY, Lee MJ, Cho SH, Kim SB, Lee ST, Min SK. Comparison of Clinical Symptoms Scored According to NIH-CPSI in Patients with Chronic Prostatitis Syndrome Category IIIa and IIIb. Korean J UTII. 2011;6(1):42-46

9. Shoskes DA, Hakim L, Ghoniem G, Jackson CL. Long-term results of multimodal therapy for chronic prostatitis/chronic pelvic pain syndrome. J Urol. 2003;169(4):1406-1410.

10. Cho IR. Textbook of Andrology. Seoul: Koonja. 2004:571.

11. Mo XW, Wang B, Li HS, Dang J, Hang L. The Scheme and Method of TCM in Treating CP. World Chinese Medicine. 2013;8(10):1244-1245.

12. Wang YP, Cai H, Zhou JZ, Tang QQ. Relativity between cutaneous region and point application therapy. CJTCMP. 2012;27(6):1554-1555.

13. LAI JQ. Fu tie liao fa lin chuang ying yong ti hui(敷貼療法臨床應用體會). Modern Journal of Integrated Traditional Chinese and Western Medicine. 2008;17(10):1534-1535.

14. Nie ZL, Sun PJ, Nie M. Gao re yin fa e xing zhong liu xiao tui de re li xue gen ju. Medical Information. 2011;24(8):4840-4841.

15. Wang N. Ti wai gao pin re liao lian he yao wu zhi liao 227 li manxing qian lie xian yan liao xiao guan cha. Contemporary Medicine, 2008;14(23):145-146.

\section{ORCID}

$\begin{array}{ll}\text { 서희정 } & \text { https://orcid.org/0000-0002-8238-8891 } \\ \text { 배고은 } & \text { https://orcid.org/0000-0002-4315-8129 } \\ \text { 서형범 } & \text { https://orcid.org/0000-0002-3992-0686 }\end{array}$

